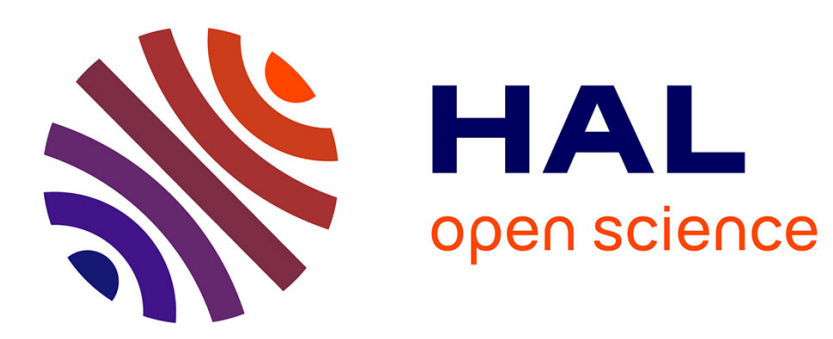

\title{
Teaching Competence for Organising Problem-Centred Teaching-Learning Process
}

\author{
Renata Jonina, David Oget, Jacques Audran
}

\section{To cite this version:}

Renata Jonina, David Oget, Jacques Audran. Teaching Competence for Organising Problem-Centred Teaching-Learning Process. TRIZ - The Theory of Inventive Problem Solving Current Research and Trends in French Academic Institutions, Springer International Publishing, pp.85-104, 2017, 10.1007/978-3-319-56593-4_4. hal-02898953

\section{HAL Id: hal-02898953 \\ https://hal.science/hal-02898953}

Submitted on 14 Jul 2020

HAL is a multi-disciplinary open access archive for the deposit and dissemination of scientific research documents, whether they are published or not. The documents may come from teaching and research institutions in France or abroad, or from public or private research centers.
L'archive ouverte pluridisciplinaire HAL, est destinée au dépôt et à la diffusion de documents scientifiques de niveau recherche, publiés ou non, émanant des établissements d'enseignement et de recherche français ou étrangers, des laboratoires publics ou privés. 


\title{
Authors version
}

Jonina, R., Oget, D., \& Audran, J. (2017) Teaching Competence for Organising Problem-Centred Teaching-Learning Process. In: Cavallucci D. (ed) TRIZ - The Theory of Inventive Problem Solving. Springer.

DOI: https://doi.org/10.1007/978-3-319-56593-4 4

\section{Teaching Competence for Organising Problem-Centred Teaching-Learning Process}

\author{
Renata JONINA ${ }^{1}$, David OGET ${ }^{2}$ and Jacques AUDRAN ${ }^{3}$ \\ ${ }^{1}$ University of Strasbourg, 67000 Strasbourg, France \\ 2INSA Strasbourg, 67000 Strasbourg, France \\ ${ }^{3}$ INSA Strasbourg, 67000 Strasbourg, France
}

\begin{abstract}
The problem-centred education (PCE) is a teaching-learning process which includes meta-subject tools as part of its content. The given tools, which find their origin in OTSM-TRIZ theories, allow to structure and reorganise information with the aim of identifying, analysing and solving problems in various domains. In the framework of the PCE students develop not only their subject-matter skills (e.g. language, maths, etc.) but also their problem solving competence or inventive thinking skills. While the research has shown that the PCE has had a positive impact on learners, the empirical experience of helping regular school teachers learn to organise problem centred teaching-learning process showed that while some teachers succeeded to introduce some changes, the majority of them failed to introduce any changes in their classrooms. The given situation has brought to the foreground the problem of teaching competence required from a teacher for organising problem-centred teaching-learning process. The given chapter will define the PCE highlighting the features which differ it from the existing problem-based and teaching for thinking approaches and will present the first results of the study into the teaching competence required for organising problem-centred teaching learning process.
\end{abstract}




\section{Keywords}

Problem-centred education, teaching competence, inventive thinking skills, problem solving competence, OTSM-TRIZ models, teaching for thinking approaches

\section{Defining the Problem-Centred Education}

\section{a. Educational Context and the Problem-Centred Education}

The need to develop students' higher-order thinking skills and problem solving competence in the framework of school education has already been highlighted since the middle of the $20^{\text {th }}$ century. Nowadays, the given requirement has been shifted to the foreground of educational agenda due to the radical changes the world has been going through on its way from industrial society to information society (Lyotard, 1984; Paul \& Foray, 2002), imposing on a person the demand to "have a stock of informationprocessing skills, including literacy, numeracy and problem solving, and "generic" skills, such as interpersonal communication, self-management, and the ability to learn [...]" (OECD, 2013a, p. 46). At the same time, the recent international research results highlight that neither modern students reach successful results in terms of literacies and problem solving abilities for successful functioning in knowledge society (OECD, 2013b, 2014), nor teachers seem to have relevant teaching competence for organising the teaching-learning process that would meet the needs of the modern school (Izglīīibas Attīstības Centrs, 2008; Leat, 1999; OECD, 2005; Sawyer, 2006; Sternberg \& Martin, 1988).

In the educational literature the approaches and programmes which target the development of higher-order thinking skills and problem solving competence are referred to as approaches for teaching higher-order thinking (Zohar, 1999, 2004, 2008; Zohar \& Schwartzer, 2005), approaches for teaching thinking skills (Adey, 1999; Adey \& Shayer, 1993, 1994; Avargil, 
Herscovitz, \& Dori, 2012; Johnson \& Siegel, 2010; McGregor, 2007; McGuiness, 1999; Moseley, Elliott, Gregson, \& Higgins, 2005), inquirybased instruction (Baumfield, 2006; Baumfield, Butterworth, \& Edwards, Gail, 2005; Dostál, 2015; Lehrer, Schauble, \& Lucas, 2008; Windschitl, 2003), problem-based educational approaches (Barrows, 1996; Barrows \& Tamblyn, 1980; Матюшкин, 1972; Махмутов, 1977; Мельникова, 2002), cognitive-activation instruction (Echazarra, Salinas, Mendez, Denis, \& Rech, 2016, p. 35), teaching for understanding (Fennema \& Romberg, 1999; Perkins, 1993, 1998; Perkins \& Blythe, 1994; Wiskey, 1997) and the like. I apply the umbrella term 'teaching for thinking approaches' to refer to this family of approaches, programmes and methodologies. Having different theoretical backgrounds and being different in their specific focus, all teaching for thinking approaches rely on the constructive or socioconstructive theory of learning making students active participants of the teaching-learning process and involving them in constructing their understanding rather than practicing rote memorisation and recall of information. In addition, all of them promote relevant thinking dispositions (e.g., being persistent, thinking flexibly, adopting a questioning attitude), encourage the language of thinking (such as summarise, estimate, conclude, imply) which allow associating thinking words with their relevant cognitive processes, develop meta-cognition, and teach transferring of knowledge, skills, dispositions and strategies to students' everyday lives (Burke \& Williams, 2008). Moreover, all these approaches target to develop students' conceptual understanding of phenomena under study in the framework of the subject-matter teaching (be it science, math, languages or any other school subject). Hence, they blend subject-matter content instruction with explicit instruction about thinking skills and processes and are often called infusion approaches (McGuiness, 1999; Moseley et al., 2005).

Despite a lot of positive features which characterise teaching for thinking approaches, none of them relies on any problem solving theory that would serve as the basis for developing students' problem solving competence (Sokol, 2007; Sokol, Lasevich, Jonina, \& Dobrovolska-Stoian, 2013; Sokol, Oget, Sonntag, \& Khomenko, 2008, p. 34). The Problem-Centred Education, on the other hand, relies on the General Theory of Powerful Thinking 
(OTSM) and the Theory of Inventive Problem Solving (TRIZ) (Altshuller, 1984, 1986, Хоменко, 1993, 2008; Хоменко \& Аштиани, 2007) and offers to integrate into the teaching-learning process domain independent tools (which in educational context I refer to as meta-subject tools) for managing information in the process of problem solving. The given domain independent tools uncover the cognitive process which leads to solving a problem as it is viewed in OTSM-TRIZ.

So, on the one hand, the Problem-Centred Education can be considered to be a part of the teaching for thinking family since it shares its core features: the view on socio-constructive nature of learning, the content of education as a blend of subject-matter content and explicit thinking instruction, development of meta-cognition and promotion of relevant thinking dispositions. On the other hand, relying on the OTSM-TRIZ problem solving theories, the Problem-Centred Education adds a new content into the teaching-learning process, namely, OTSM-TRIZ models and technologies, thus targeting the development of additional cognitive skills and dispositions, which in the framework of the Problem-Centred Education are referred to as inventive thinking skills and dispositions or problem solving competence (Sokol, 2007; Sokol, Lasevich, Jonina, et al., 2013). Therefore it would be legitimate to say that teaching competence for organising problem-centred teach-

Problem solving competence or inventive thinking skills: "an ability and disposition to solve linguistic, sociolinguistic, pragmatic and other kinds of problems when no typical solution is available" (Sokol, 2007, p. 56) and avoiding a large number of trials and errors (Sokol, 2007, p. 46). ing-learning process can also be referred to as teaching competence for organising teaching learning process aimed at the development of students' inventive thinking skills and dispositions in the framework of the subject-matter instruction (see Fig. 1).

\footnotetext{
* From Russian общая теория сильного мышления (ОТСМ), Теория решения изобретательсктх задач (ТРИЗ).
} 


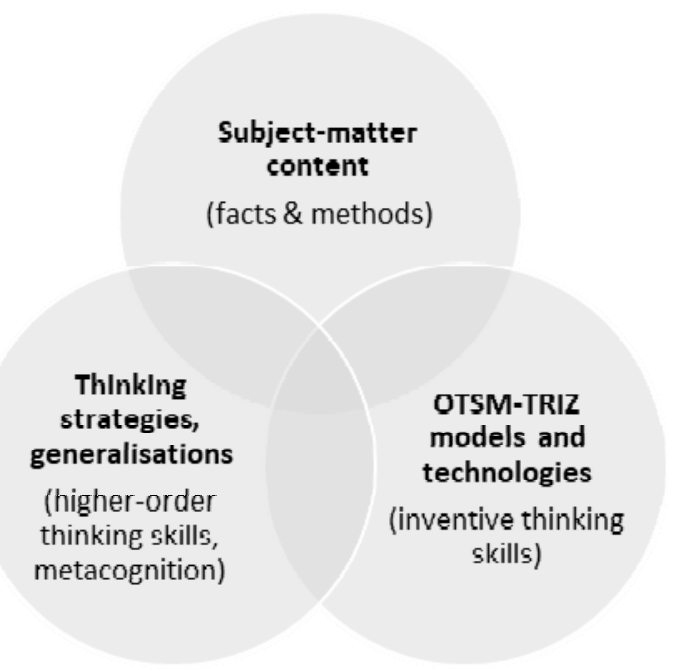

Figure 1 The Main Content Components of the Problem-Centred Education: General View

\section{b. TRIZ-Based Educational Movements and the Problem- Centred Education}

The Problem-Centred Education is an umbrella term and is also referred to as OTSM-TRIZ pedagogy (Терехова \& Нестеренко, 2012). It includes complexes of pedagogical technologies based on the system of OTSM-TRIZ models and technologies which I refer to as domain-independent tools or meta-subject tools. Currently, it includes three developed pedagogical technologies: technologies for developing imagination, thinking and speech of pre-school children (Сидорчук, 1998), technologies of problemcentred education (Нестеренко, 2006a) and technologies of the thinking approach to language teaching and learning (Sokol, 2007). 
The Problem-Centred Education should be distinguished from other so called TRIZ-based educational movements ${ }^{+}$. Even though, all of them set the priority of developing creative personality able to define and solve problems in different domains, and apply classical TRIZ, TRTL ${ }^{\ddagger}$ and RTB ${ }^{\S}$ instruments as its theoretical basis, the content they offer to teach is different. If the classical TRIZ pedagogy keeps the classical TRIZ content as much as possible, then the Problem-Centred Education is using the improved instruments of classical TRIZ and new OTSM instruments for working with inter-disciplinary problems (Терехова \& Нестеренко, 2012, р. 40). Moreover, in the framework of the Problem-Based Education, the instruments are integrated in the subject-matter content. For instance, the Thinking Approach to language teaching and learning (Sokol, 2007) offers technologies for developing inventive thinking skills while learning English as a foreign language.

Another aspect which is important to highlight is the instruction or the organisation of the teaching-learning process as such which stands behind the content. Any content can be presented to students in a form of a lecture or a scattered set of tasks and lack to involve students in meaningful learning activity, which would not eventually bring to the effective development of their problem solving competence. The Problem-Centred Education relies on a socio-constructive view on learning (Vygotsky, 1978; Леонтьев, Запорожец, Гальперин, \& Эльконин, 2005) and is based on the idea of a non-linear nature of learning and thus non-linear organisation of teaching-learning process. This has certain implications on how the process of content acquisition is organised and may differ the ProblemCentred Education from other TRIZ-based educational movements.

Even though the line between the TRIZ-based educational movements may seem blurred, the difference becomes much more apparent once the

\footnotetext{
${ }^{\dagger}$ For the comprehensive review of TRIZ-based educational movements refer to (Терехова \& Нестеренко, 2012)

‡ TRTL, from Russian «Теория развития творческой личности», Theory of the development of creative personality.

$\S$ RTB, from Russian «Развитие творческого воображения», Development of creative imagination.
} 
observation of the real teaching-learning process where students are involved in learning activities that lead to the development of their inventive thinking skills is held on a long-term basis.

\section{c. Aims, Definition, Content and Instruction of the Problem- Centred Education}

\section{Aims and Definition}

The development of the Problem-Centred education has been driven by the contradictions between a constantly increasing content of education which appears as a result of a general trend of ever-increasing volume of information and speed at which it becomes outdated, of the reduced amount of time available for the acquisition of this content and of vagueness or even absence of information that students will need in future. Hence, the driving problem of education was formulated as follows: "teachers must prepare students to the life that teachers know nothing about"(Мурашковска \& Хоменко, 2003, р. 32). The offered conceptual solution has been to move away from structuring educational content by division of content into subjects (see Fig. 2) to organizing it through the study of a problem (Мурашковска, 2004, p. 5) (see Fig. 3).

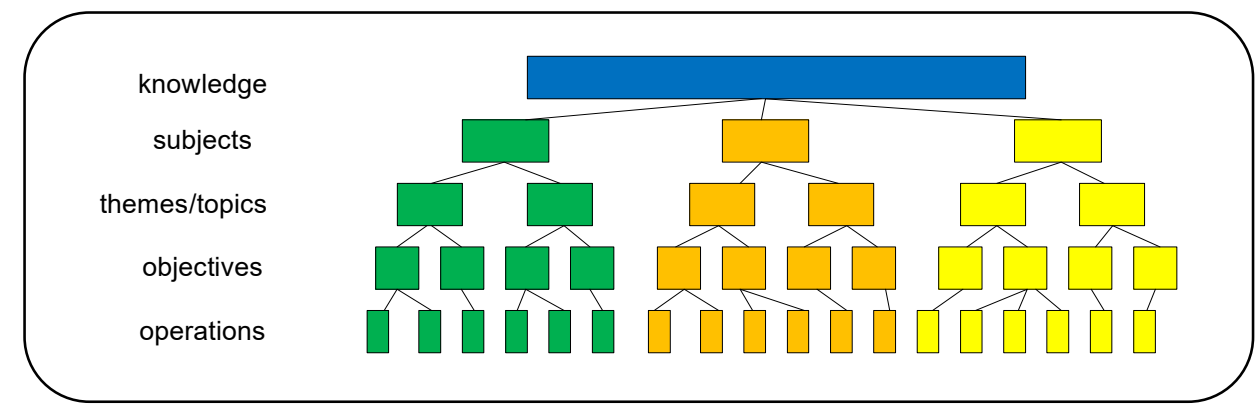

Figure 2 Model of the structure of education content guided by division of content into subjects (Мурашковска, 2004, р. 2). 
In other words, a problem should become a cornerstone, a pivotal component for organization of educational content, the central value in the system (Sokol, 2007; Нестеренко, 2006a, 2006b, 2007) and the domain independent models for defining, analysing and solving problems should become its new structural content component (Нестеренко, 2006а).

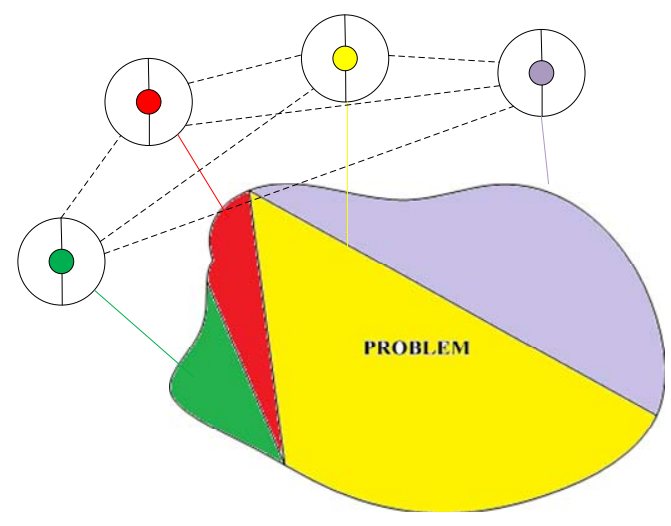

Figure 3 Model of the structure of education content guided by the study of a problem (Мурашковска, 2004, р. 8).

The aim of the Problem-Centred Education is then formulated as "the development of a world view centred on a problem" (Sokol, 2007, p. 43) and the Problem-Centred Education is defined as "a teaching-learning process which includes meta-subject tools as part of its content; the given metasubject tools allow to structure and reorganise information with the aim of identifying, analysing and solving problems in various domains" (Нестеренко, 2006а, pp. 3, 13)

The Problem-Centred Education has been explicitly aiming at helping learners develop skills which are necessary for coping with so called nontypical (creative) problems in various domains avoiding a large number of trials and errors (Sokol, 2007; Sokol et al., 2008, p. 34), where a non-typical problem has been conceptualised as "the one for which no solution exists or is not known to the problem-solver" (Sokol et al., 2008, p. 34). The cognitive skills and dispositions which are targeted to be developed in the 
Problem-centred education: "a teachinglearning process which includes meta-subject tools as part of its content; the given metasubject tools allow to structure and reorganise information with the aim of identifying, analysing and solving problems in various domains" (Нестеренко, 2006, pp. 3, 13) framework of the Problem-Centred teachinglearning process are referred to as inventive thinking skills (see Fig. 4).

\section{Content}

The content of the Problem-Centred Education contains three main structural components: subject-matter or subject-specific information and thinking strategies which form the building blocks of problem situations and OTSM-TRIZ models and technologies referred to as domainindependent tools used to work with the subject-specific information transforming problem situations into solutions (see Fig. 5).

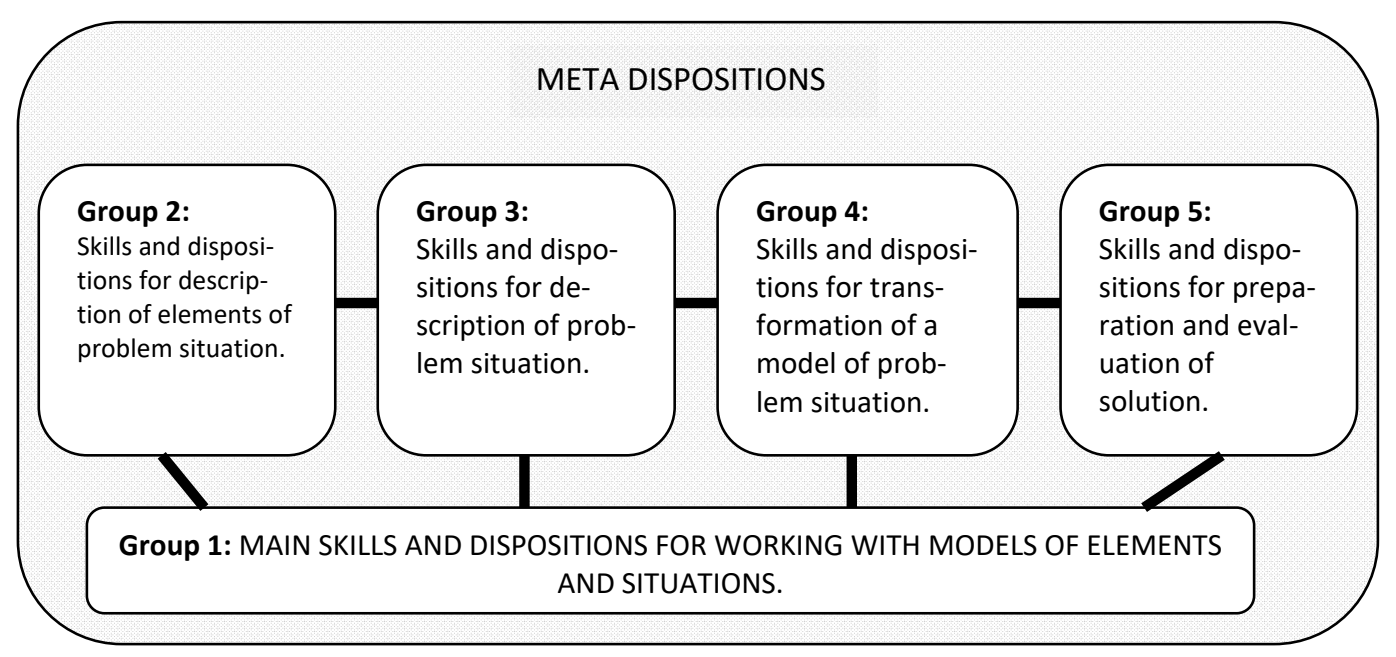

Figure 4 Structure of inventive thinking (Sokol, 2007, p. 46)

The subject-matter content gets a new format. If subject-matter content is considered to have three structural components - (1) facts which describe objects and processes, (2) strategies which describe transformation of objects and processes, i.e. operations or algorithms of transformations, and 
(3) dispositions, which include beliefs, values, and attitudes - then in the framework of the PCE, students are working with the models of objects and processes and with the models of transformation and strategies.

A model is viewed as "a system represented in mind or in a material world, which being a representation or a reproduction of an object of the study is able to substitute that object in such a way that the study of that representation/reproduction allows us to discover new information about the object itself' (Штофф В.А., 1966, с 19 in Нестеренко, 2006а, р. 35). In other words, models are a schematic, rough representation of reality. They "constitute a bridge between the observational and theoretical levels; and are concerned with simplification, reduction, concretization, experimentation, action, extension, globalization, theory formation and explanation" (Apostel, 1961, p. 3 in Chorley \& Haggett, 2014, p. 24).

For example, instead of teaching students specific facts, such as specific historical events, they are offered a general model of a historical event which is described through a specific set of interconnected parameters. The next step is to build a model of any event which will further serve as a model for describing specific events, be it historical, economic, cultural or the like. The same holds true about procedures or methods for action. Instead of teaching students how to identify causes of a specific historical event, they can be build a more general model of how to identify causes of any fact and this model will serve as a basis for various specific procedures (Нестеренко, 2006а).

Building theoretical models allow efficient organisation and transformation of information in the process of problem solving. The developed models further serve as a basis for newly acquired information and as a result work on diminishing the amount of separate content components which traditionally have to be acquired in the subject-matter teachinglearning process. The focus of work shifts from finding a solution to building a strategy for developing solutions when dealing with a given type of tasks. However, as a result, students are not so much supposed to acquire a pool of separate models as to learn HOW to build new models when they face a problem. In order to ensure the effective organisation of the above defined teaching-learning process students should be provided with metasubject tools that would allow them to build specific models for specific learning contexts. 
The meta-subject tools used in the framework of the Problem-Centered Education are the improved instruments of classical TRIZ and new OTSM instruments for working with inter-disciplinary problems. These include the ENV model and the Advanced ENV model (or the Multi-screen model), and a set of ARIZ models. Working with these meta-tools should lead to the development of inventive thinking skills presented in Fig. $4^{* *}$.

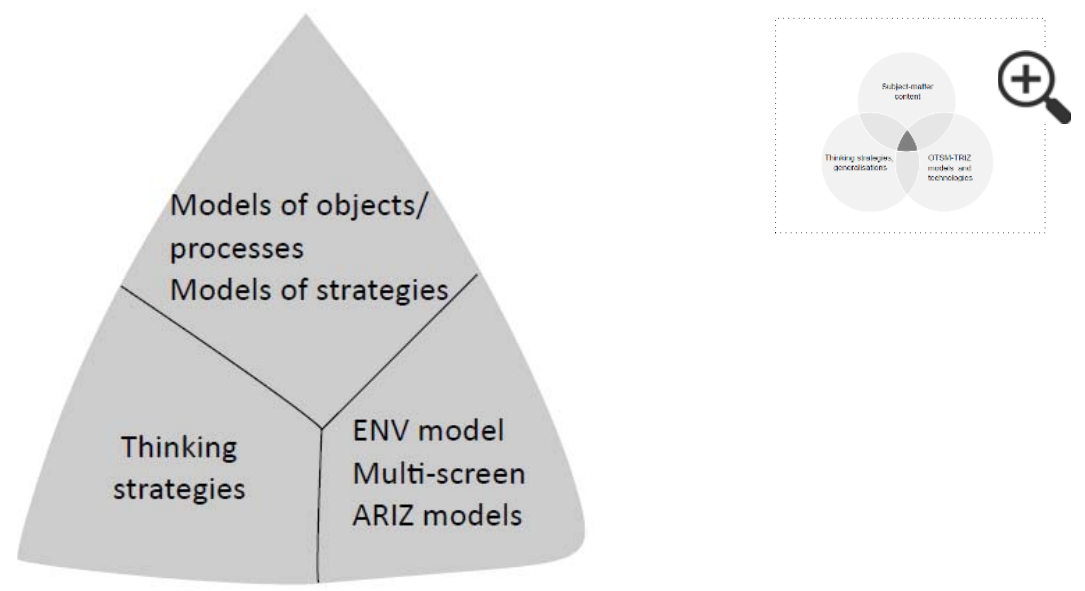

Figure 5 The Main Content Components of the Problem-Centred Education: Specific View

\section{Instruction}

The PCE relies on findings from several psychological theories when it comes to building the teaching-learning process, the main ones being the socio-cultural theory of learning (Vygotsky, 1978) and activity theory (Гальперин, 2011; Леонтьев et al., 2005) including theory of developmental education (Давыдов, 1996). Moreover, it takes into account information processing perspective on human cognition or schema theory (R. C. Anderson, 1978, 1984) and various implications of cognitive approaches to learning (Adey, Hewitt, Hewitt, \& Landau, 2004; L. W. Anderson, 2004;

\footnotetext{
${ }^{* *}$ The detailed list of inventive thinking skills defined under each group presented in Fig.4 can be found in (Appendix 1.1 Sokol, 2007)
} 
Bloom, 1984; Emery \& Wilks, 1998; Ferretti, MacArthur, \& Okolo, 2001; Steve Higgins et al., 2004; Steven Higgins \& Baumfield, 1998; KoufettaMenicou \& Scaife, 2000; Krathwohl, 2002; Li, 2011; Naisbett, 1997; Topping \& Trickey, 2007; Zohar \& Schwartzer, 2005), as well as implications of problem education (Кудрявцев, 1991; Лернер, 1982; Матюшкин, 1972; Махмутов, 1977; Мельникова, 2002).

The main implications of these theories for the Problem-Centred Education are manifested in (1) the instructional sequence, (2) method of teaching and (3) dialogic approach in teacher-student interaction.

Within the problem-centred teaching-learning process the instruction is organized through the three steps represented in the Thinking Task Framework (Sokol, 2011; Sokol, Lasevich, \& Jonina, 2013) (see Fig. 6).

\section{Thinking Task Framework}

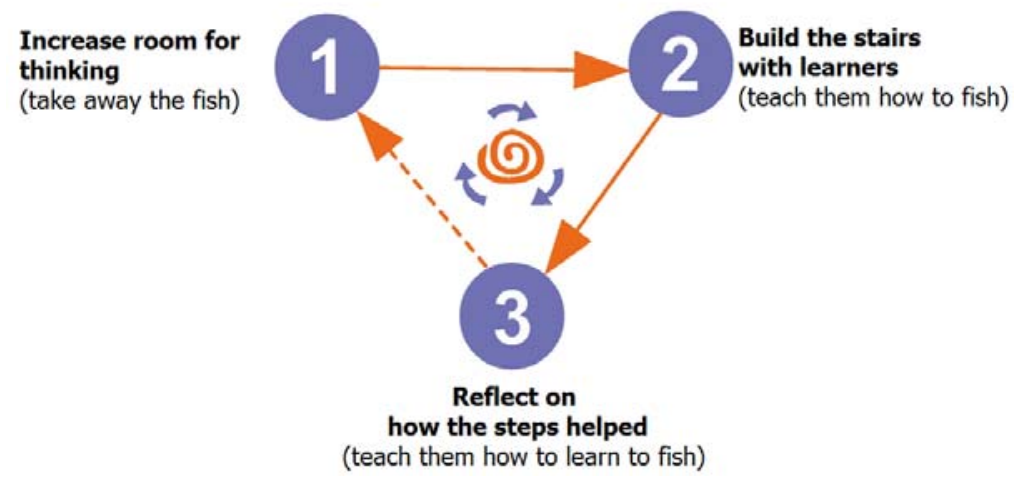

Figure 6 The Thinking Task Framework (Sokol, 2011; Sokol, Lasevich, \& Jonina, 2013)

In step one step, which is suggesting to 'increase room for thinking', students are given a problem task which causes a problem situation (Матюшкин, 1972; Махмутов, 1975; Мельникова, 2002) or a cognitive conflict (Adey, 1999; Adey \& Shayer, 1994) in student's minds. The second step invites a teacher to 'build the stairs with learners', which can be in- 
terpreted as helping students build models with the help of meta-tools. This step involves applying psychological mechanisms of learning and managing the learning activity of students instead of merely letting them look for the solution following a trial and error method. In the psychological literature the given process is referred to as scaffolding (Vygotsky, 1978). It includes developing a system of sub-tasks which would keep challenging students cognitively and would involve students in learning activity leading to building a model or a strategy. This step also includes pursuing students' reasoning. The last step is reflection when students are asked to reflect on the process (procedural steps that helped to build the models), on the meta-tools which helped to build the model and on the model itself, its quality, application scope and limitations. In this step, as well as throughout the process, students are also involved in reflecting on thinking strategies that were used in the process.

Speaking about the method of teaching, it is worth making a distinction between the method of teaching and tools of teaching or resources of teaching (Лернер, 1982). The teaching-learning process is the unity of the activity of a teacher and the activity of a learner. Tools or resources that a teacher can use in this process can be represented in different forms: graphical or pictorial (images, graphs, videos, etc.), in a form of tangible objects (microscope, book, experimental material, etc.) and in a verbal form (story, lecture, explanation, etc.). And a method of teaching is a way of organising learners' activity with the tools or resources, i.e. method of organisation of learners' cognitive activity. Any tool or resource can be used for the purposes of different methods. For instance, a simple picture can be presented to learners and accompanied by teacher's narration. In this teaching-learning situation, learners' cognitive activity will be limited to perception and awareness of new information. If learners are invited to answer questions about the picture they've just heard of, then their cognitive activity is involved in reproduction of knowledge and possibly methods. And only when students are given a picture and a task connected to its analysis, their cognitive activity raises to problem solving (Лернер, 1982). The main method of teaching in the Problem-Centred Education is the research method (or the method of inquiry). 
The dialogic approach in teaching-student interaction means that a teacher should have competence in organizing a qualitative dialogue with students while pursuing students' reasoning in the teaching-learning process.

The organization of the above defined problem-centred teaching-learning process requires specific competences from the teacher. The empirical experience $^{+t}$ showed the lack of understanding of which exactly competences are required from a teacher for organizing the problem-centred teaching-learning process and why some teachers are more successful in this endeavor while others fail to change their usual teaching habits.

\section{The Study of Teaching Competence for Problem-Centred Education}

\section{a. Teacher Competence and Teaching Competence}

After analysing different approaches to defining teacher competences in Europe, the Thematic Working Group 'Teacher Professional Development' (The European Commission, 2011, 2013) concluded that approaches vary a lot and range from general guidelines (for instance in France, Hungary or Luxembourg) to detailed lists of specific competences (for instance, in Estonia, the Netherlands, the UK). Despite the differences, the international review of both policy documents and research studies done by the Thematic Working Group (The European Commission, 2013, pp. 45-46) allowed to identify key aspects of teacher competences that are commonly mentioned in the majority of studies. These are regrouped in three areas or structural components: knowledge and understanding, skills, and dispositions (which include beliefs, attitudes, values and commitment).

\footnotetext{
${ }^{++}$Among other projects and professional development events there were two international projects supported by the Nordic Council of Ministers in the framework of the Nordplus Horizontal programme which led to this conclusion:

- 2010-2012 Bringing Creativity and Thinking Skills in Educational Process;

- 2012-2014 STEP to Thinking - Summer Schools for Teachers Professional Development.
} 
As stated by Caena (Caena, 2011; The European Commission, 2013) teacher competences imply a wider, systemic view of teacher professionalism, and considers the multi-faceted roles of the teacher on multiple levels the individual, the school, the local community, professional networks. Whereas teaching competences are focused on the role of the teacher in action in the classroom, directly linked with the 'craft' of teaching - with professional knowledge and skills mobilised for action. It can thus be defined as "[...] complex combinations of knowledge, skills, understanding, values and attitudes, leading to effective action in situation. Since teaching is much more than a task, and involves values or assumptions concerning education, learning and society [...]" (The European Commission, 2013, p. 8).

We can, thus, assume then that in order to solve the problem of the lack of understanding of knowledge, skills and dispositions mobilized for action in a problem-centred classroom, a teacher in action has to be studied, and a wider understanding of his underlying knowledge and dispositions has to be sought for. The author has initiated the research which aims at studying teachers' experience of working with the problem-centred education with the aim of identifying criteria and indicators of teaching competence required for organising the problem-centred teaching-learning process. The study described further on is a part of this larger research and is focused on studying instructional patterns of a teacher in action who is organising the problem-centred teaching-learning process.

\section{b. The Study of a Teacher in Action Organising the Problem- Centred Teaching-Learning Process}

\section{Study problem and aim}

The specific problem the study addressed was to reveal whether there is any core difference in classroom instruction between teachers who are experts in organising the problem-centred teaching-learning process and those who are non-experts. 
The aim of the study was thus to identify instructional patterns of expert teachers who build their classroom instruction following the three steps of the Thinking Task Framework (see Fig. 6) and to compare them to those of non-expert teachers. In addition to identifying instructional patterns the study focused on comparing the quality of teacher-student interaction of expert and non-expert teachers.

The given chapter presents the results of the study on one expert teacher (referred further as T2-nk) and focuses only on identification of her instructional patterns.

\section{Research base}

The expert teacher whose lessons were analyzed was a Russian as a mother tongue teacher, the head of the Russian language department in the secondary school in Latvia (Daugavpils). The teacher was named as an expert since she had more than 3 years of experience of working with the problem-centred education. In addition, she had more than 10 years of experience of working with the Developmental Education (Давыдов, 1996) and in 1997 she received the title of the best teacher of Russian as a mother tongue.

\section{Data collection method}

The permission was obtained from T2-nk to observe and film her lessons during which she was purposefully working through the three steps of the Thinking Task Framework organising the problem-centred teachinglearning process. During one month, from September 2013 to October 2013, the researcher was attending and filming her lessons, occasionally recording the teacher's comments on her own lessons. As a result 16 lessons (40 minutes each) were filmed with forms eight (two groups) and nine (two groups).

\section{Data selection logic}


Two consecutive lessons of T2-nk were selected for the purpose of the study analysis since the teacher introduced a new grammar topic. Nonstructured interviews of the teacher on her own lesson were recorded. The next four consecutive lessons were selected since these were held with the same group of students and teacher continued working with the same grammar topic. Non-structured interview of the teacher on her prelast lesson was recorded. As a result, 6 lessons were selected for the analysis.

\section{Data analysis method}

In order to identify instructional patterns, the study adapted the analytic approach to modelling the teaching process developed by Teacher Model Group at the University of California at Berkeley, Graduate School of Education (Schoenfeld, 1998a, 1998b, 2000, 2011). The Teacher Model Group developed the model of classroom teaching (teacher-in-action). The core components of the model are based on the assumption that the teacher "has" knowledge, goals and beliefs, makes decisions and takes actions. The model of the teacher, thus, contains representations of knowledge, goals and beliefs attributed to the teacher, and the decisionmaking mechanism that suggests what actions the teacher is likely to take (Schoenfeld, 2000, p. 249). The model has a descriptive nature and can be used to characterize, in extremely fine-grained detail, what happens in a given teaching session and used for making predictions about teacher's classroom instruction in various circumstances.

\section{Procedure of the study}

The study followed the following procedure:

1. The researcher transcribed all the six lessons of T2-nk;

2. The first two consecutive lessons were then analysed together since they constituted one unit. The same was further done for two other lessons and then, two remaining lessons. 
3. The first lesson was divided into 6 episodes and the second lesson into 8 episodes (large action sequences) each containing brief summary of the content of that episode.

4. Each episode (large action sequence) was then parsed into smaller action sequences going down to the level of 'simple talk' (see Fig. 7 for an example of a parsed lesson). Each action sequence was characterized by triggering and terminating event, as well as beliefs, goals, and knowledge attributed to the teacher.

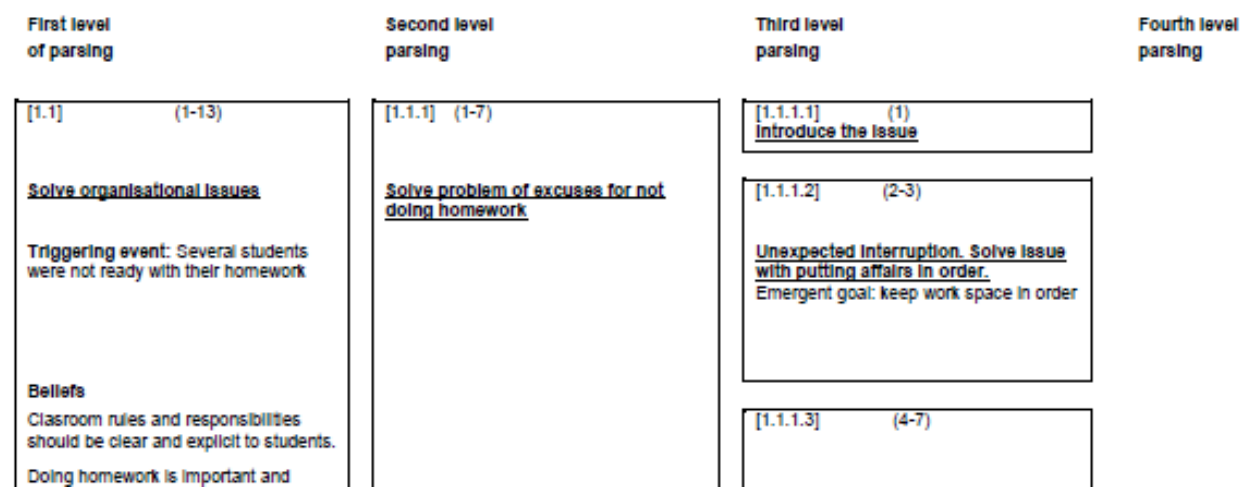

Figure 7 Extract of one example of a parsed lesson

5. The discussion on the parsing was held with the peer following the principles of competitive argumentation. (VanLehn, Brown, \& Greeno, 1984). The general idea of competitive argumentation is that "it's the investigator's responsibility to consider all possible explanations of the situation being examined, and then look at the pro- and con- evidence for each. If every explanation but one is discredited, and that one is credible, then it's the best explanation" (from the personal email correspondence with Alan Schoenfeld, January 01, 2014). The first parsing was then refined through multiple iterations.

6. After the lesson was parsed, the researcher proceeded to identifying the action sequences where the teacher organised learners' 
work with the system of tasks (a problem task and sub-tasks) following the instruction defined by the Thinking Task Framework. The guiding question was to identify whether there is a specific pattern (routine) how the teacher worked through these tasks.

\section{Results and discussion}

Doing the same analysis for all the six lessons allowed me to identify a certain pattern in how T2-nk works through the system of problem tasks following the Thinking Task Framework (see Fig. 8). I refer to this pattern as a loop instruction.

As can be seen from Figure 8 , the teacher starts with offering students the main problem task, which involves students in the first learning activity in the form of an individual work, pair work or group work. As a result of this activity, students produce their first result, which is then discussed in a plenary session during the teacher-student interaction ${ }^{\ddagger \neq}$. The result of this interaction is involvement of students into the second learning activity during which they work on improving their first result taking into account the conclusions of the plenary session. This is specifically during the second learning activity that the real learning is taking place since students apply new understandings gained during the stage of the social construction of the meaning to the problem task. Students never start doing any other task before they work on the improvement of their first result. The given loop instruction can be repeated several times in the framework of doing one task.

I would assume that organising the instruction in the format of the loop allows planning enough time and steps for learners to build a model or a strategy. Moreover, this is specifically during the first teacher-students' interaction that students have to be offered or reminded of the meta-

\footnotetext{
\# The quality of this interaction is highly important and as stated in the section on 'study problem and aim' it was also assessed following certain defined criteria. The results of this quality assessment are not reported in this article.
} 
subject tools which have to help them build their model or strategy. I can tentatively assume then that the competence of organizing the instruction in a form of a loop seems to be essential if one wants to work with the problem-centred education.

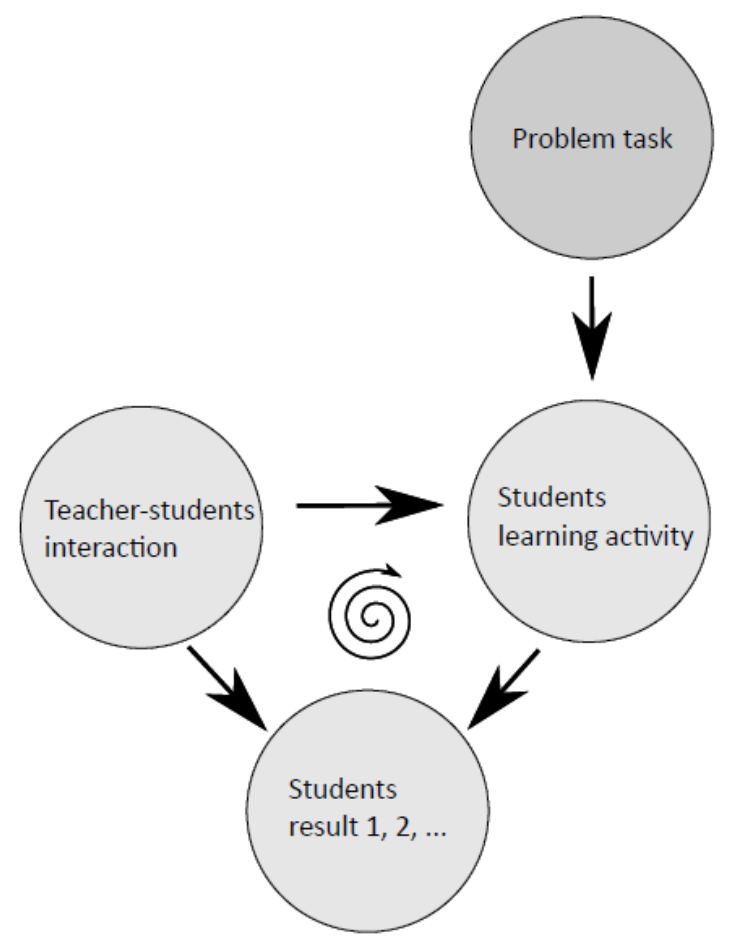

Figure 8 An expert teacher's (T2-nk) instructional pattern for working through a system of problem tasks following the Thinking Task Framework in the framework of the problem-centred teaching-learning process

The meticulous analysis of the expert teacher in action has to be repeated for other expert teachers as well before any conclusion on a common pattern can be made or any specific conclusions drawn. In addition, this pattern has to be compared to non-expert teachers' instruction in order to reveal the main difference between the two and identify those essential components of classroom instruction which make expert teachers succeed in organizing the problem-centred teaching-learning process and which are missing in the instruction of non-expert teachers. 


\section{Conclusions}

The given chapter presented a brief overview of the essence of the problem-centred education and the respective teaching-learning process.

This provided the implications on the general competences (i.e. knowledge and understanding, skills and dispositions) a teacher needs in order to be able to organize the defined process. These competences include both those which are specific for the problem-centred education (PCE) and those which are shared with other teaching for thinking approaches and make part of the competences required for organizing effective teachinglearning process as such.

Among others, these essential competences include the following:

1. Aims and objectives of the Problem-Centred Education

- Dispositions:

0 belief in the need to develop students' worldview centred on a problem;

0 belief in the constructive nature of learning.

2. Content of the Problem-Centred Education

- Knowledge and understanding:

o knowledge and understanding of the subject matter being taught;

o knowledge and understanding of mental modeling and strategy development;

0 knowledge and understanding of the meta-subject OTSM-TRIZ tools;

o knowledge and understanding of inventive thinking skills and their connection to the meta-subject OTSMTRIZ tools;

0 knowledge and understanding of thinking strategies and higher-order thinking skills

- Skills

o Skills to select the relevant subject-matter content, single out features common for specific types of tasks within that content, and transform this content into a system of problem tasks (a problem task and sub-tasks) 
that would create and maintain cognitive conflict in students minds and that requires developing a model or a strategy. The task should have the potential of applying the meta-subject tools for developing the model, strategy.

3. Instruction of the Problem-Centred Education

- Skills

o ability to organize the instruction following the three steps of the Thinking Task Framework: create cognitive conflict or a problem situation in student's mind, involve students in learning activity for building the solution and reflect on the process and result.

0 ability to use the method of inquiry for organising students' learning activity;

o ability to hold qualitative teacher-student interaction;

The weaknesses of the given general list are twofold: firstly, the list is not complete and secondly, it is too general.

In order to address the given weakness, the author initiated the research that should result in measurable criteria and indicators of the problemcentred teaching competence. The first study presented in the given chapter focused on classroom instruction and allowed to identify a specific loop instruction which seems to be one of the characteristics of teachers who are experts in the problem-centred education. Further study is required in order to confirm the given hypothesis and to extend the understanding of teaching competence required for organizing the problem-centred teaching-learning process. 


\section{References}

1. Adey, P. (1999). The Science of Thinking, and Science for Thinking: A Description of Cognitive Acceleration through Science Education (CASE). UNESCO: International Bureau of Education.

2. Adey, P., Hewitt, G., Hewitt, J., \& Landau, N. (2004). The professional development of teachers: practice and theory. New York, Boston, Dordrecht, Lonon, Moscow: Kluwer Academic Publishing.

3. Adey, P., \& Shayer, M. (1993). An Exploration of Long-Term Far-Transfer Effects Following an Extended Intervention Program in the High School Science Curriculum. Cognition and Instruction, 11(1), 1-29.

4. Adey, P., \& Shayer, M. (1994). Really Raising Standards: Cognitive Intervention and Academic Achievement. London; New York: Routledge.

5. Altshuller, G. (1984). Creativity as an exact science: the theory of the solution of inventive problems. New York: Gordon and Breach Science Publishers.

6. Altshuller, G. (1986). To find an idea: An introduction into the theory of inventive problem solving (in Russian). Novosibirsk: Nauka.

7. Anderson, L. W. (2004). Increasing teacher effectiveness (2nd Edition). Paris, France: UNESCO: International Institute for Educational Planning.

8. Anderson, R. C. (1978). Schema-Directed Processes in Language Comprehension. In A. M. Lesgold, J. W. Pellegrino, S. D. Fokkema, \& R. Glaser (Eds.), Cognitive Psychology and Instruction (pp. 67-82). Springer US.

9. Anderson, R. C. (1984). The Notion of Schemata and the Educational Enterprise: General Discussion of the Conference. In R. C. Anderson, R. J. Spiro, \& W. E. Montague (Eds.), Schooling and the Acquisition of Knowledge (pp. 415-31). Lawrence Erlbaum.

10. Avargil, S., Herscovitz, O., \& Dori, Y. J. (2012). Teaching Thinking Skills in ContextBased Learning: Teachers' Challenges and Assessment Knowledge. Journal of Science Education and Technology, 21(2), 207-225.

11. Barrows, H. S. (1996). Problem-based learning in medicine and beyond: A brief overview. New Directions for Teaching and Learning, 1996(68), 3-12.

12. Barrows, H. S., \& Tamblyn, R. M. (1980). Problem-Based Learning: An Approach to Medical Education. Springer Publishing Company.

13. Baumfield, V. (2006). Tools for Pedagogical Inquiry: The Impact of Teaching Thinking Skills on Teachers. Oxford Review of Education, 32(2), 185-196.

14. Baumfield, V., Butterworth, M., \& Edwards, Gail. (2005). The impact of the implementation of thinking skills programmes and approaches on teachers (Research Evidence in Education Library) (p. 69). London: EPPI-Centre, Social Science Research Unit, Institute of Education, University of London.

15. Bloom, B. S. (1984). Taxonomy of Educational Objectives Book 1: Cognitive Domain (2nd edition edition). New York: Addison Wesley Publishing Company. 
16. Burke, L. A., \& Williams, J. M. (2008). Developing Young Thinkers: An intervention aimed to enhance children's thinking skills. Thinking Skills and Creativity, 3(2), 104-124.

17. Caena, F. (2011, April). Literature review: Teachers' core competences: requirements and development. European Commission.

18. Chorley, R., \& Haggett, P. (2014). Physical and Information Models in Geography (Reissue edition). London: Routledge.

19. Dostál, J. (2015). The Draft of The Competencial Model of The Teacher in The Context of The Inquiry-Based Instruction. Procedia - Social and Behavioral Sciences, 186, 998-1006.

20. Echazarra, A., Salinas, D., Mendez, I., Denis, V., \& Rech, G. (2016). How Teachers Teach and Students Learn: Successful Strategies for School (OECD Education Working Papers No. 130). Paris, France: OECD.

21. Emery, L., \& Wilks, S. (1998). Aesthetics and critical thinking in visual arts education. Australian Art Education, 21(1), 61.

22. Fennema, E., \& Romberg, T. A. (1999). Mathematics Classrooms That Promote Understanding. Mahwah, N.J: Routledge.

23. Ferretti, R. P., MacArthur, C. D., \& Okolo, C. M. (2001). Teaching for historical understanding in inclusive classrooms. Learning Disability Quarterly, 24(1).

24. Higgins, S., \& Baumfield, V. (1998). A Defence of Teaching General Thinking Skills. Journal of Philosophy of Education, 32(3), 391-398.

25. Higgins, S., Baumfield, V., Mei, L., Moseley, D., Butterworth, M., Graham, D., ... Thacker, D. (2004). Thinking skills approaches to effective teaching and learning: what is the evidence for impact on learners? (Research Evidence in Education Library). London: EPPI-Centre, Social Science Research Unit, Institute of Education, University of London.

26. Izglīīibas Attīstības Centrs. (2008). Kritiskās domāšanas attīstī̌sanas pieejas izmantošana izglītības sistēmā - ietekme un efektivitāte Latvijā (p. 32). Riga, Latvia: Izglītības Attīstības Centrs.

27. Johnson, S., \& Siegel, H. (2010). Teaching thinking skills. (C. Winch, Ed.). London; New York, NY: Continuum International Pub. Group.

28. Koufetta-Menicou, C., \& Scaife, J. (2000). Teachers' questions types and significance in science education. School Science Review, 81, 79-84.

29. Krathwohl, D. (2002). A revision of Bloom's taxonomy: An overview. Theory Into Practice, 41(4), 212-218.

30. Leat, D. (1999). Rolling the Stone Uphill: Teacher Development and the Implementation of Thinking Skills Programmes. Oxford Review of Education, 25(3), 387-403.

31. Lehrer, R., Schauble, L., \& Lucas, D. (2008). Supporting development of the epistemology of inquiry. Cognitive Development, 23(4), 512-529.

32. Li, L. (2011). Obstacles and opportunities for developing thinking through interaction in language classrooms. Thinking Skills and Creativity, 6(3), 146-158. 
33. Lyotard, J.-F. (1984). The Postmodern Condition: A Report on Knowledge. (G. Bennington \& B. Massumi, Trans.). Manchester: Manchester University Press.

34. McGregor, D. (2007). Developing Thinking; Developing Learning. Open University Press.

35. McGuiness, C. (1999). From Thinking Skills to Thinking Classrooms: a review and evaluation of approaches for developing pupils' thinking (No. RR115) (p. 36). Nottingham: DfEE.

36. Moseley, D., Elliott, J., Gregson, M., \& Higgins, S. (2005). Thinking Skills Frameworks for Use in Education and Training. British Educational Research Journal, 31(3), 367-390.

37. Naisbett, A. (1997). Policy and Provision for More Able Pupils: The Nunthorpe Experience. Support for Learning, 12(2), 83-89.

38. OECD. (2005). Teachers Matter: Attracting, Developing and Retaining Effective Teachers (Education and Training Policy) (pp. 1-237). Paris, France: OECD.

39. OECD. (2013a). OECD Skills Outlook 2013: First Results from the Survey of Adult Skills. Paris, France: OECD.

40. OECD. (2013b). PISA 2012 Results: What Students Know and Can Do (Volume I). Student Performance in Mathematics, Reading and Science. Summary in English. OECD, Paris.

41. OECD. (2014). PISA 2012 Results: Creative Problem Solving: Students' skills in tackling real-life problems (Volume V). OECD, Paris.

42. Paul, D., \& Foray, D. (2002). An introduction to the economy of the knowledge society. International Social Science Journal, 54(171), 9-23.

43. Perkins, D. (1993). Teaching for understanding. American Educator: The Professional Journal of the American Federation of Teachers, 17(3), 28-35.

44. Perkins, D. (1998). What is understanding? In M. S. Wiskey (Ed.), Teching for Understanding: Linking research with practice (pp. 39-57). San Francisko: JosseyBass.

45. Perkins, D., \& Blythe, T. (1994). Putting Understanding Up Front, 51(5), 4-7.

46. Sawyer, R. K. (2006). Educating for innovation. Thinking Skills and Creativity, 1(1), 41-48.

47. Schoenfeld, A. H. (1998a). On modeling teaching. Issues in Education, 4(1), 149162.

48. Schoenfeld, A. H. (1998b). Toward a theory of teaching-in-context. Issues in Education, 4(1), 1-94.

49. Schoenfeld, A. H. (2000). Models of the Teaching Process. The Journal of Mathematical Behavior, 18(3), 243-261.

50. Schoenfeld, A. H. (2011). How we think: a theory of goal-oriented decision making and its educational applications. New York: Routledge.

51. Sokol, A. (2007). Development of Inventive Thinking in Language Education. University of Latvia, University of Louis Pasteur Strasbourg 1, Riga, Latvia.

52. Sokol, A. (2011). Thinking Task Framework. Presented at the International Conference on Thinking, Queen's University, Belfast. 
53. Sokol, A., Lasevich, E., \& Jonina, R. (2013). A framework for bringing TRIZ based education for creative thinking to the wider audience (pp. 108-109). Presented at the Global TRIZ Conference 2013, Korea.

54. Sokol, A., Lasevich, E., Jonina, R., \& Dobrovolska-Stoian, M. (2013). Inventive Thinking Skills, Development. In E. G. Carayannis (Ed.), Encyclopedia of Creativity, Invention, Innovation and Entrepreneurship (pp. 1161-1169). Springer New York.

55. Sokol, A., Oget, D., Sonntag, M., \& Khomenko, N. (2008). The development of inventive thinking skills in the upper secondary language classroom. Thinking Skills and Creativity, 3(1), 34-46.

56. Sternberg, R. J., \& Martin, M. (1988). When Teaching Thinking Does Not Work: What Goes Wrong? Teachers College Record, 89(4), 555-78.

57. The European Commission. (2011, October 2). Policy approaches to defining and describing teacher competences. European Commission.

58. The European Commission. (2013). Supporting teacher competence development for better learning outcomes (Thematic Working Group "Teacher Professional Development") (pp. 1-59). The European Commission.

59. Topping, K. J., \& Trickey, S. (2007). Impact of philosophical enquiry on school students' interactive behaviour. Thinking Skills and Creativity, 2(2), 73-84.

60. VanLehn, K., Brown, J. S., \& Greeno, J. G. (1984). Competitive argumentation in computational theories of cognition. In W. Kintsch, J. Miller, \& P. Polson (Eds.), Methods and Tactics in Cognitive Science (pp. 235-262).

61. Vygotsky, L. S. (1978). Mind in Society. (M. Cole, Ed.). Harvard University Press.

62. Windschitl, M. (2003). Inquiry projects in science teacher education: What can investigative experiences reveal about teacher thinking and eventual classroom practice? Science Education, 87(1), 112-143.

63. Wiskey, M. S. (Ed.). (1997). Teaching for Understanding: Linking Research with Practice (1st edition). San Francisco: Jossey-Bass.

64. Zohar, A. (1999). Teachers' metacognitive knowledge and the instruction of higher order thinking. Teaching and Teacher Education, 15(4), 413-429.

65. Zohar, A. (2004). Higher Order Thinking in Science Classrooms: Students' Learning and Teachers' Professional Development (2004 edition). Dordrecht, The Netherlands; Boston: Springer.

66. Zohar, A. (2008). Teaching thinking on a national scale: Israel's pedagogical horizons. Thinking Skills and Creativity, 3(1), 77-81.

67. Zohar, A., \& Schwartzer, N. (2005). Assessing Teachers' Pedagogical Knowledge in the Context of Teaching Higher-order Thinking. International Journal of Science Education, 27(13), 1595-1620.

68. Гальперин, П. (2011). Лекции по психологии. Учебное пособие. (5-ое издание еd.). Москва: КДУ.

69. Давыдов, В. (1996). Теория развивающего обучения. ИНТОР.

70. Кудрявцев, В. Т. (1991). Проблемное обучение: истоки, сущность, перспективы. Москва: Знание. 
71. Леонтьев, А., Запорожец, А., Гальперин, П., \& Эльконин, Д. (2005). Деятельность. Сознание. Личность. Смысл, Академия.

72. Лернер, И. (1982). Развитие мышления учащихся в прочессе обучения истории. Пособие для учителей. Москва: Просвещение.

73. Матюшкин, А. (1972). Проблемные ситуации в мышлении и обучении. Москва: Педагогика.

74. Махмутов, М. И. (1975). Проблемное обучение. Основные вопросы теории. Педагогика, 246-258.

75. Махмутов, М. И. (1977). Организация проблемного обучения в школе. Просвещение.

76. Мельникова, Е. Л. (2002). Проблемный урок, или Как открывать знания с учениками: Пособие для учителя. Москва.

77. Мурашковска, И. (2004). Формирование творческой личности как проблема содержания образования. Presented at the VII научно-практическая конференция “Развитие творческих способностей детей в процессе обучения и воспитания на основе теории решения изобретательских задач (ТРИЗ)," Челябинск.

78. Мурашковска, И., \& Хоменко, Н. (2003). Третье тысячелетие: образование и педагогика. Новые ценности образования: ТРИЗ-педагогика, (1(12)), 29-34.

79. Нестеренко, А. (2006а). Дидактические модели реализации проблемноориентированного обучения (Диссертация). Академия повышения квалификации и профессиональной переподготовки работников образования, Москва.

80. Нестеренко, А. (2006b). Проблемно-ориентированный учебный процесс на базе ОТСМ-ТРИЗ.

81. Нестеренко, А. (2007). Противоречия как инструмент для проектирования педагогических систем. Presented at the Развитие творческих способностей в процессе обучения и воспитания на основе ТРИЗ, Челябинск.

82. Сидорчук, Т. (1998). Система творческих заданий как средство формирования креативности на начальном этапе становления личности. Москва.

83. Терехова, Г., \& Нестеренко, А. (2012). Современное состояние ТРИзобразования: анализ и перспективы развития. LAP Lambert Academic Publishing.

84. Хоменко, Н. (1993). Теория решения изобретательских задач (ТРИЗ) и проблемы образования (Vol. 1, p. 517). Presented at the Образование XXI века. Проблемы повышения квалификации работников образования. Тезисы докладов международной конференции, Минск: Министерство образования РБ, Институт повышения квалификации и переподготовки руководящих работников и специалистов образования, Ассоциация педагогов-исследователей РБ.

85. Хоменко, Н. (2008). Фундаментальные основы Классической ТРИз: Введение. чОУНБ 26.12.11 №3441. 
86. Хоменко, Н., \& Аштиани, М. (2007). Классическая ТРИЗ и ОТСМ как теоретическая основа инструментов для решения нестандартных проблем. Presented at the ETRIA Future 2007, Frankfurt. 